\title{
$\alpha$-Regioselective Barbier Reaction of Carbonyl Compounds and Allyl Halides Mediated by Praseodymium
}

\author{
San $\mathrm{Wu}$, Ying Li and Songlin Zhang * \\ Key Laboratory of Organic Synthesis of Jiangsu Province, College of Chemistry, \\ Chemical Engineering and Materials Science, Dushu Lake Campus, \\ Soochow University, Suzhou, 215123, People's Republic of China. \\ zhangsl@suda.edu.cn
}

NMR spectra S2-S24 




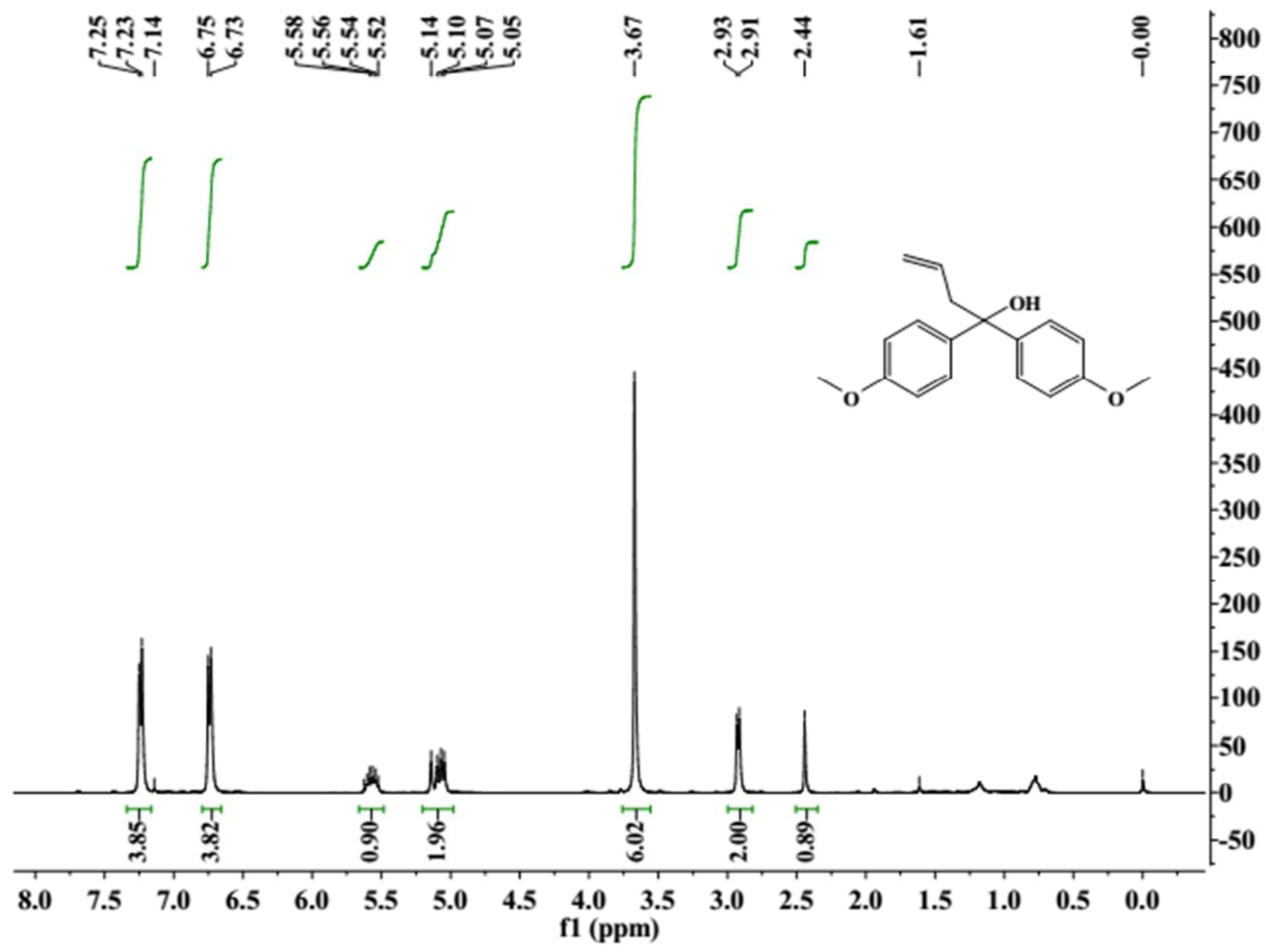



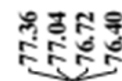

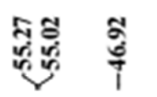

-2.4
-2.2
-2.0<smiles>CCCC(O)(c1ccc(OC)cc1)c1ccc(OC)cc1</smiles>

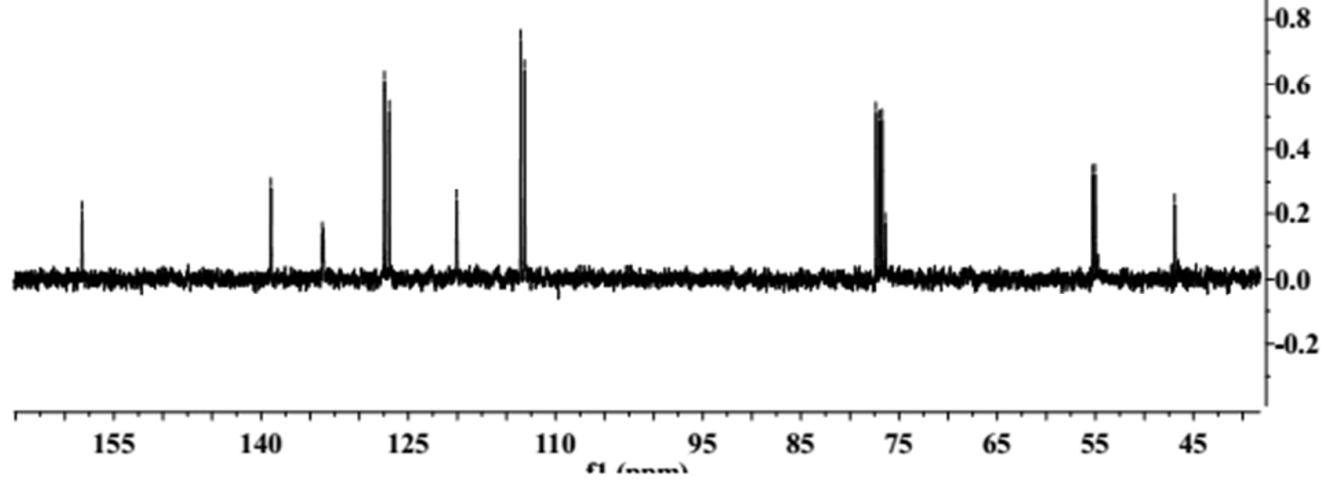




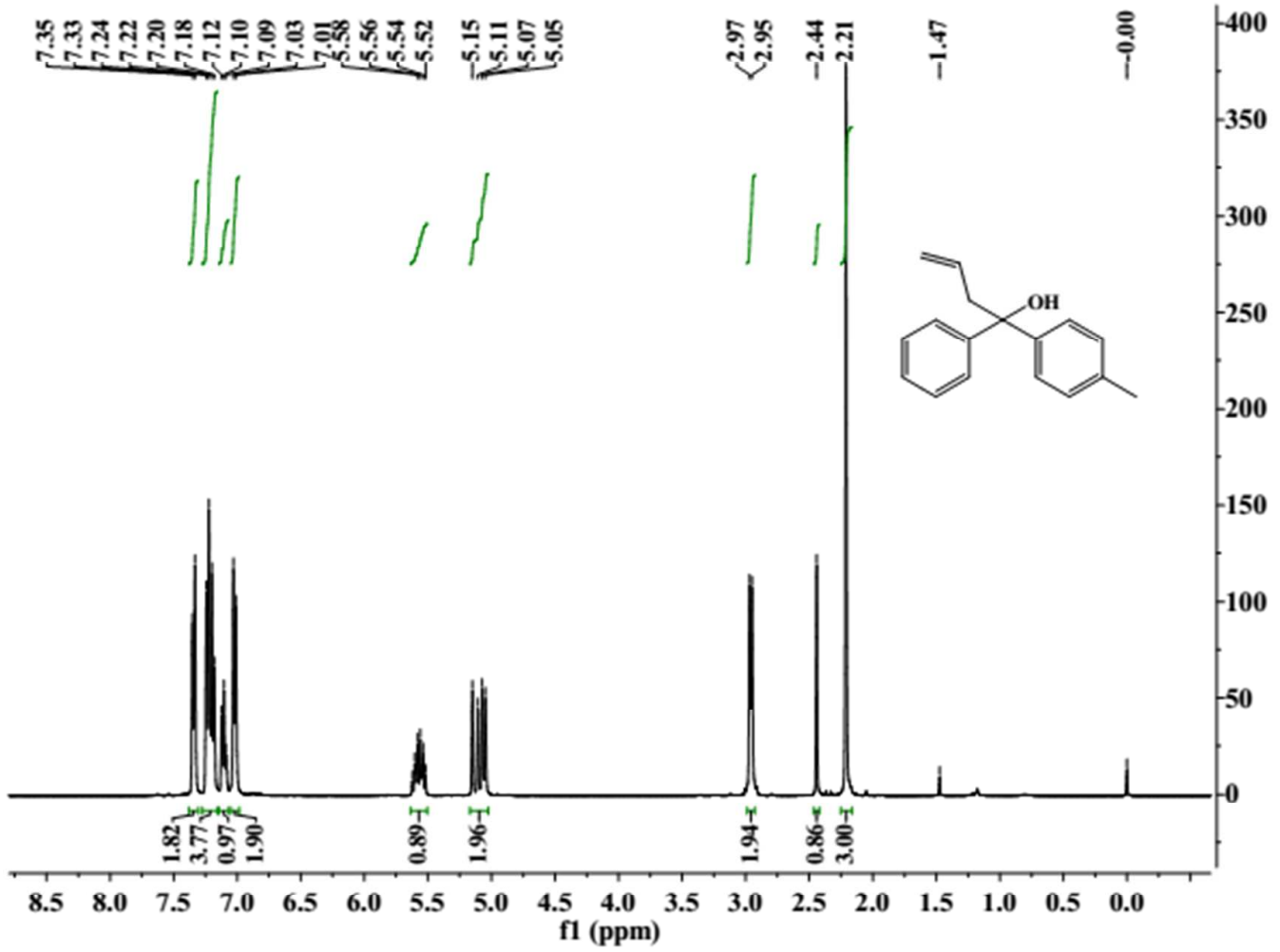




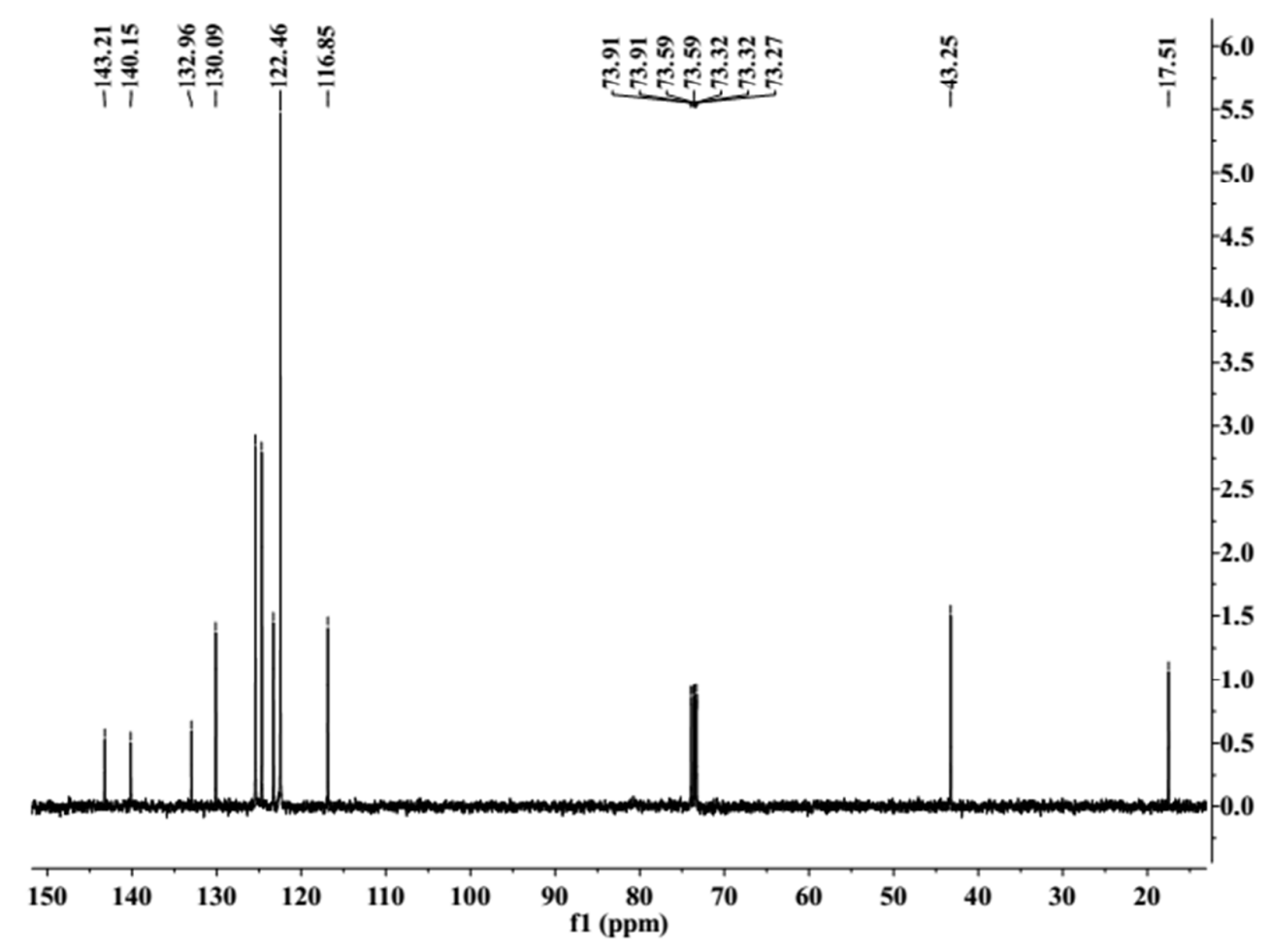

3d

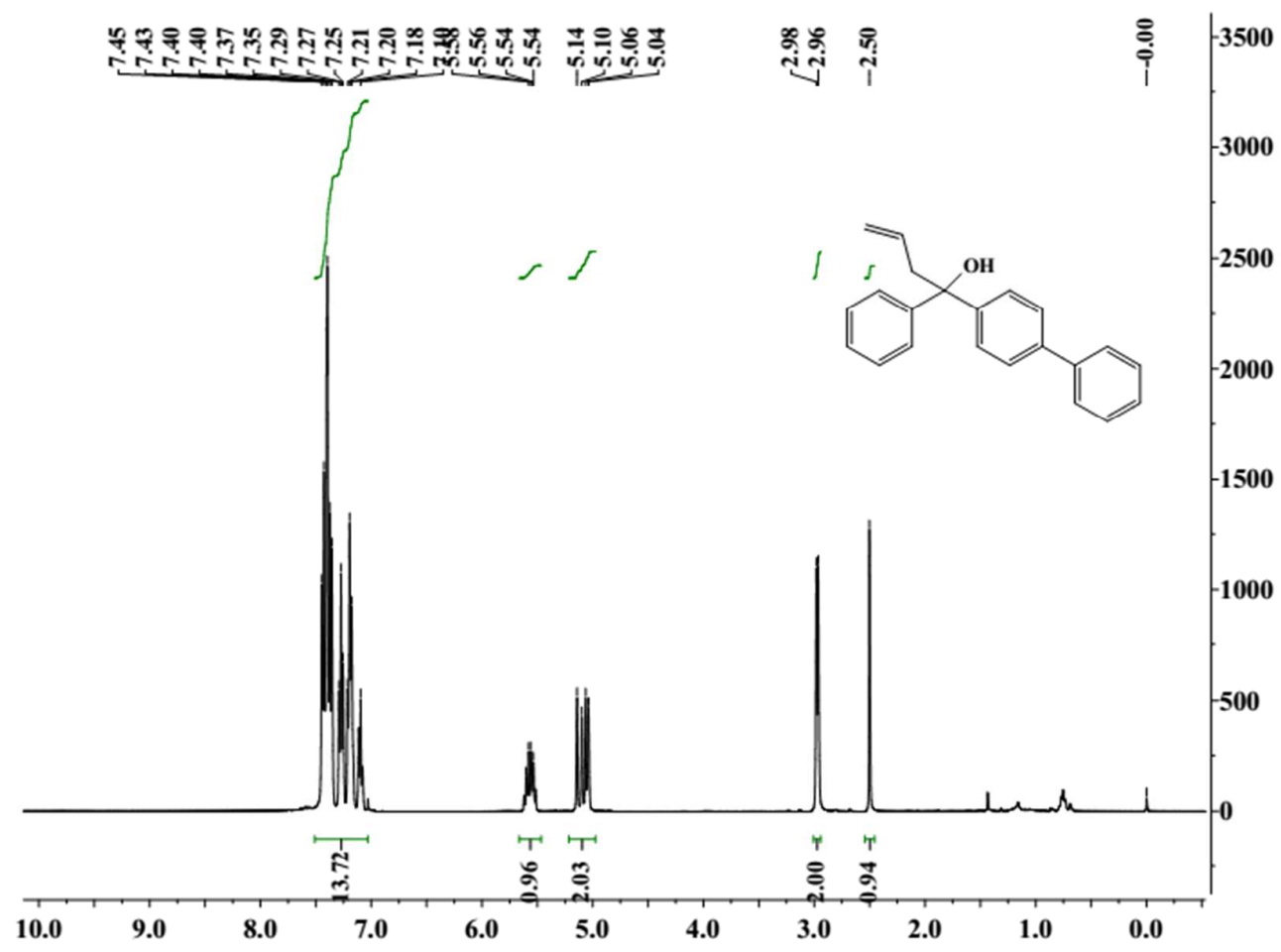




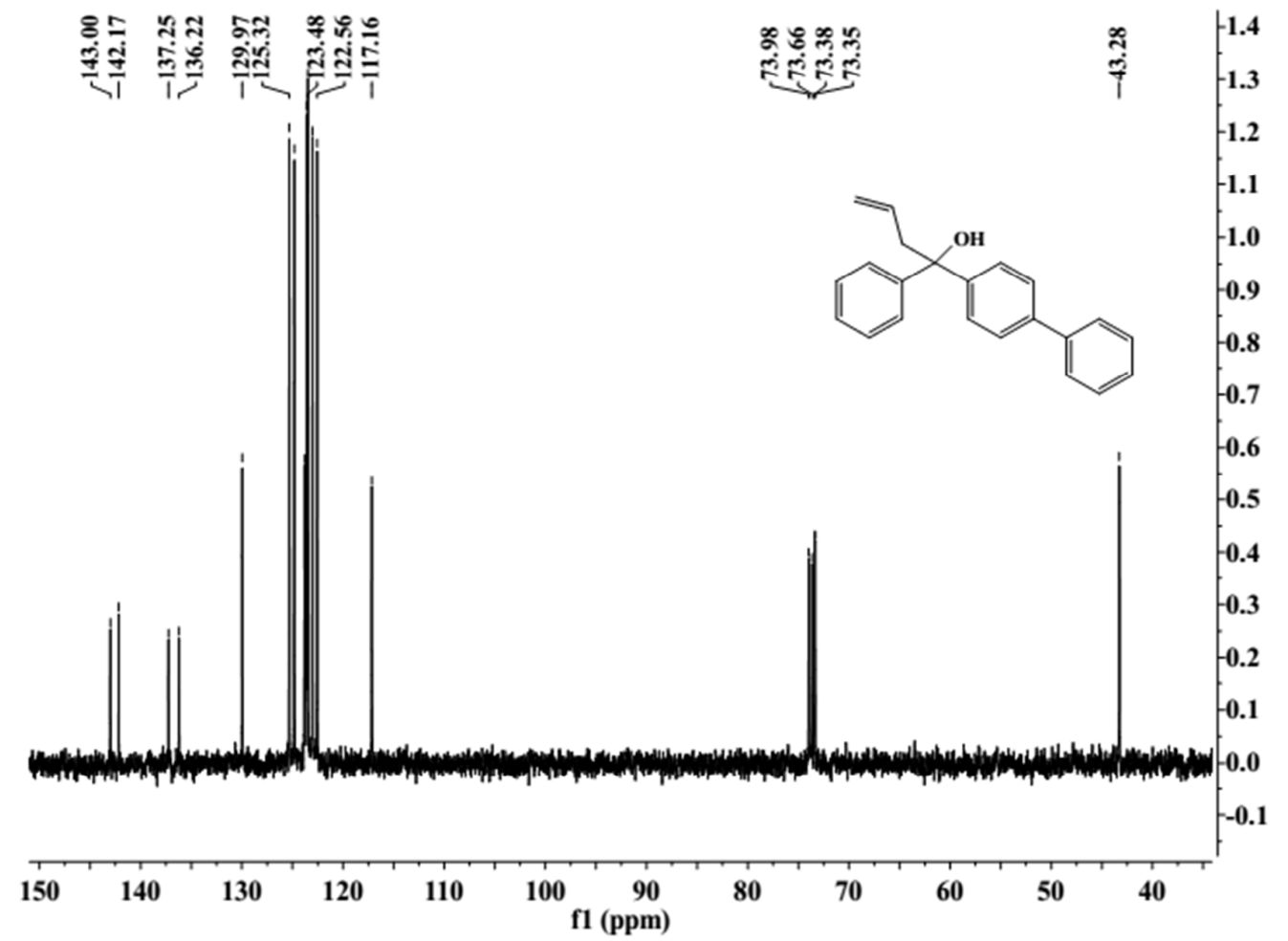

$3 e$

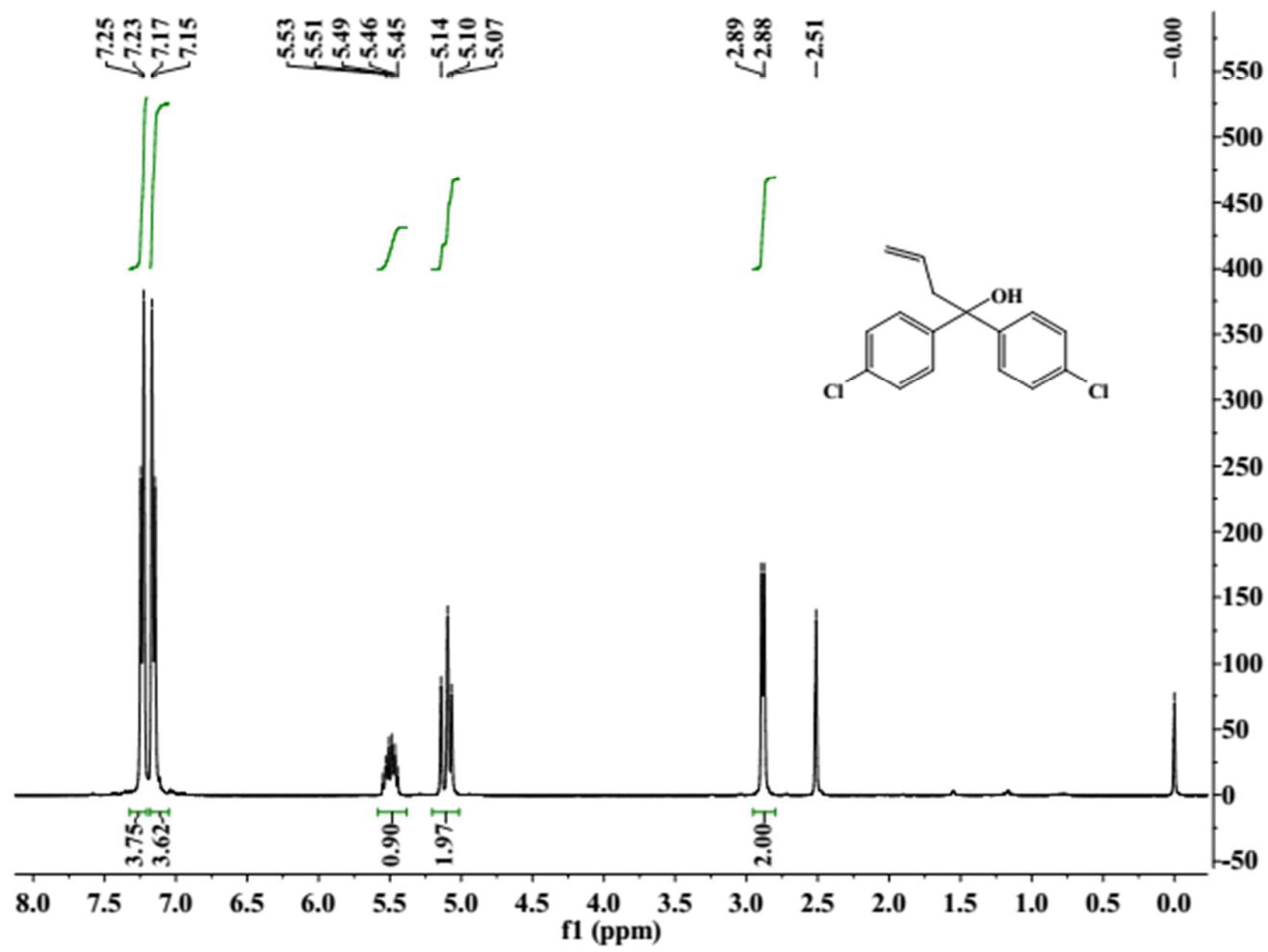




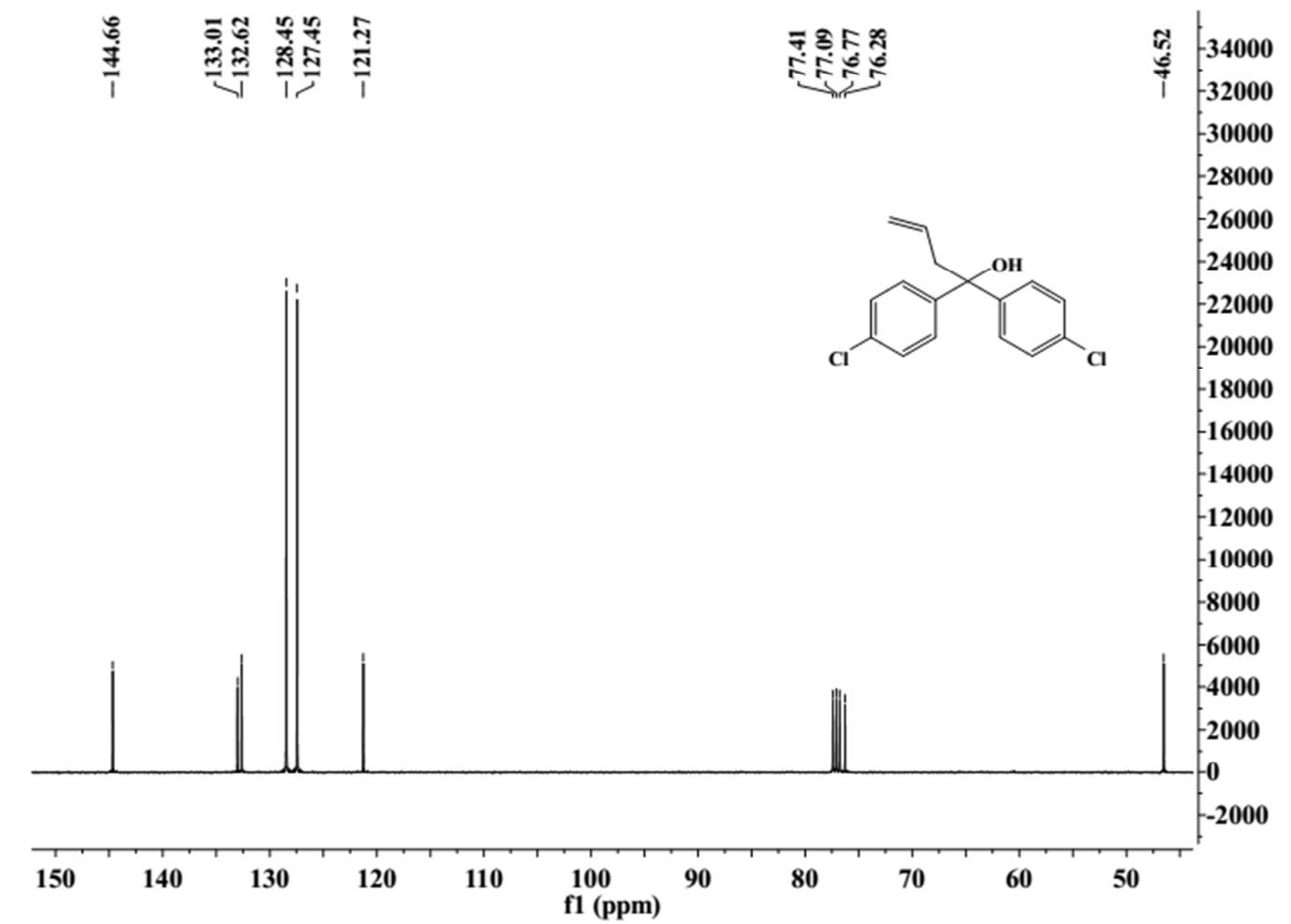

3f






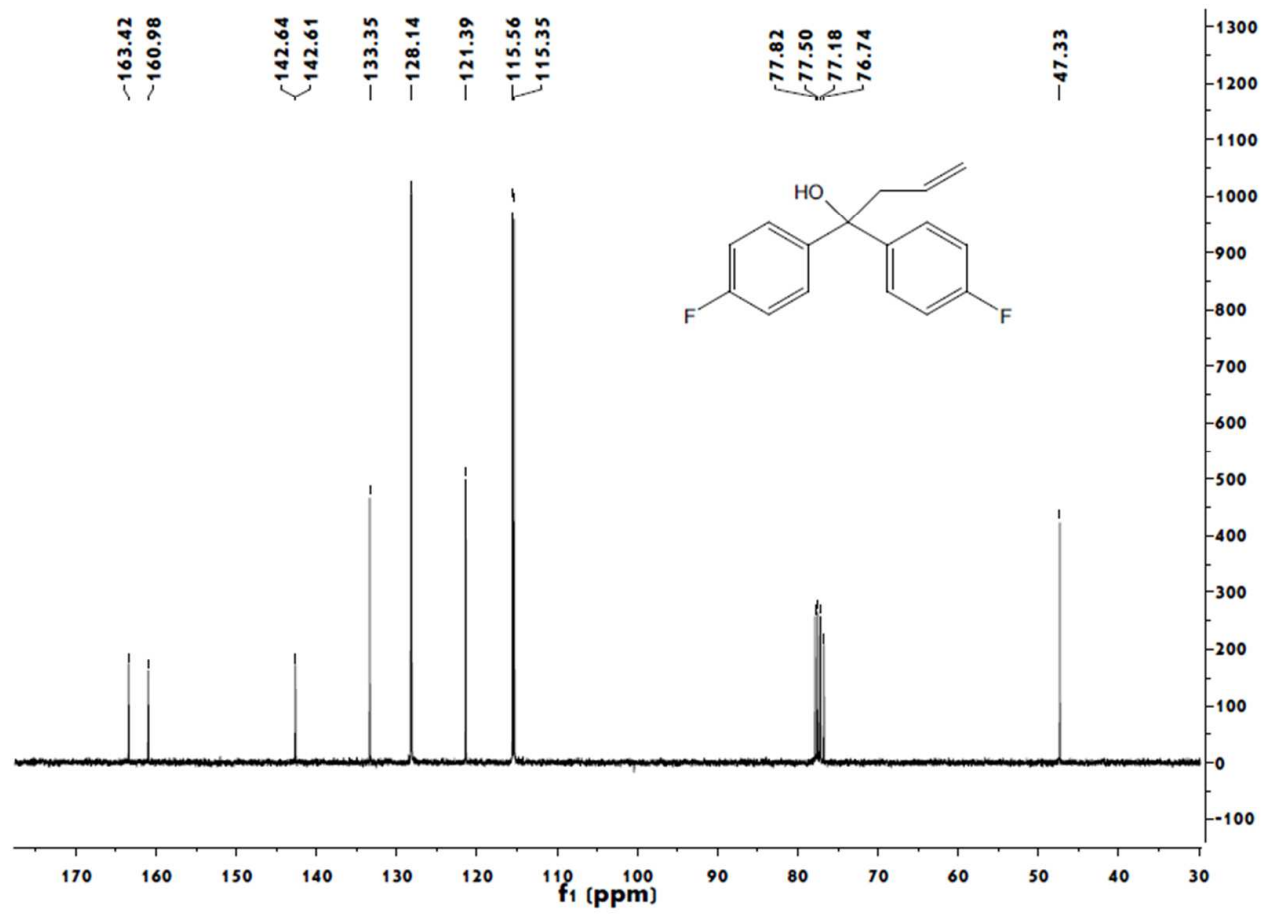

$3 g$

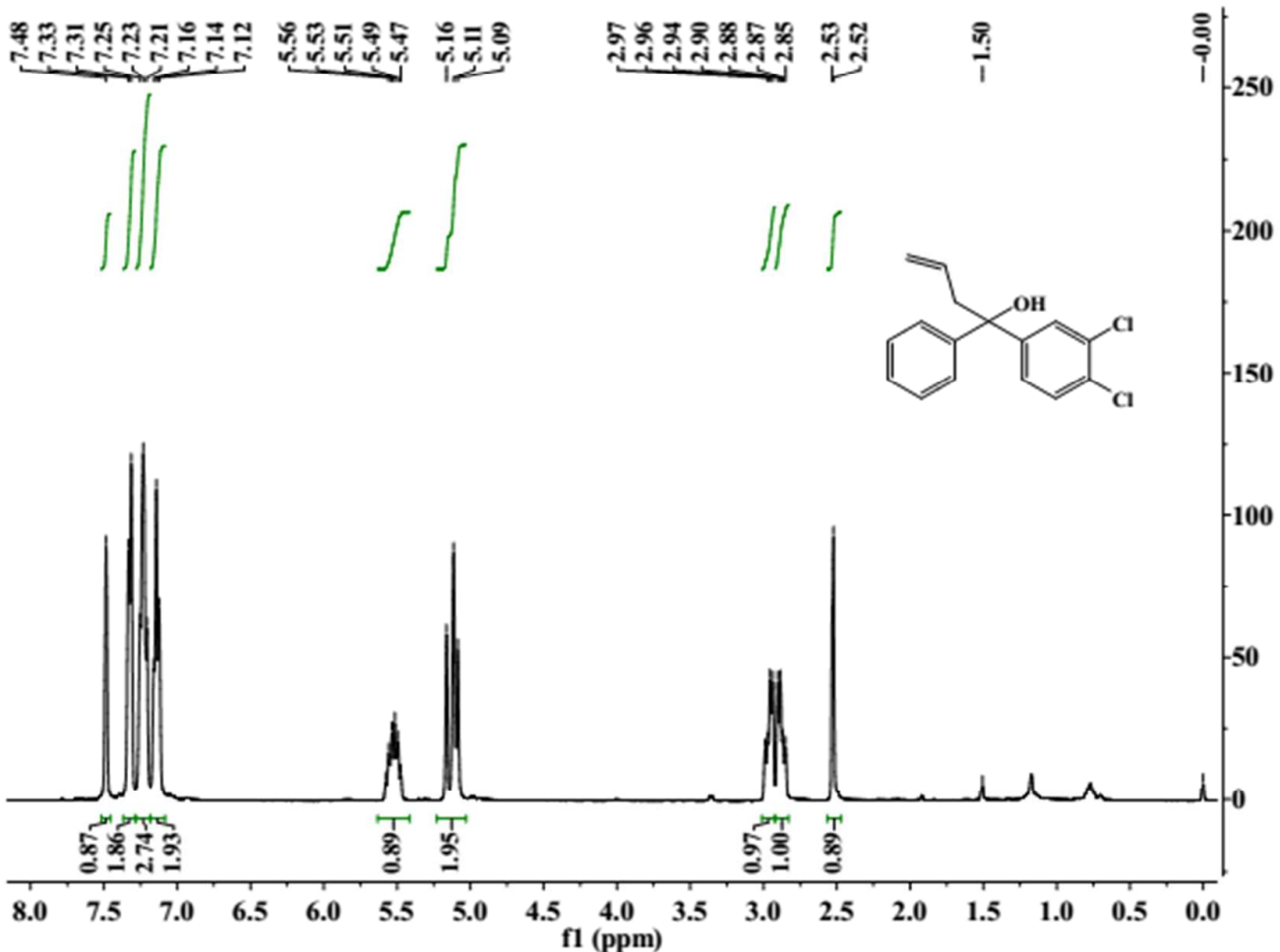




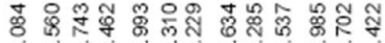
한 임
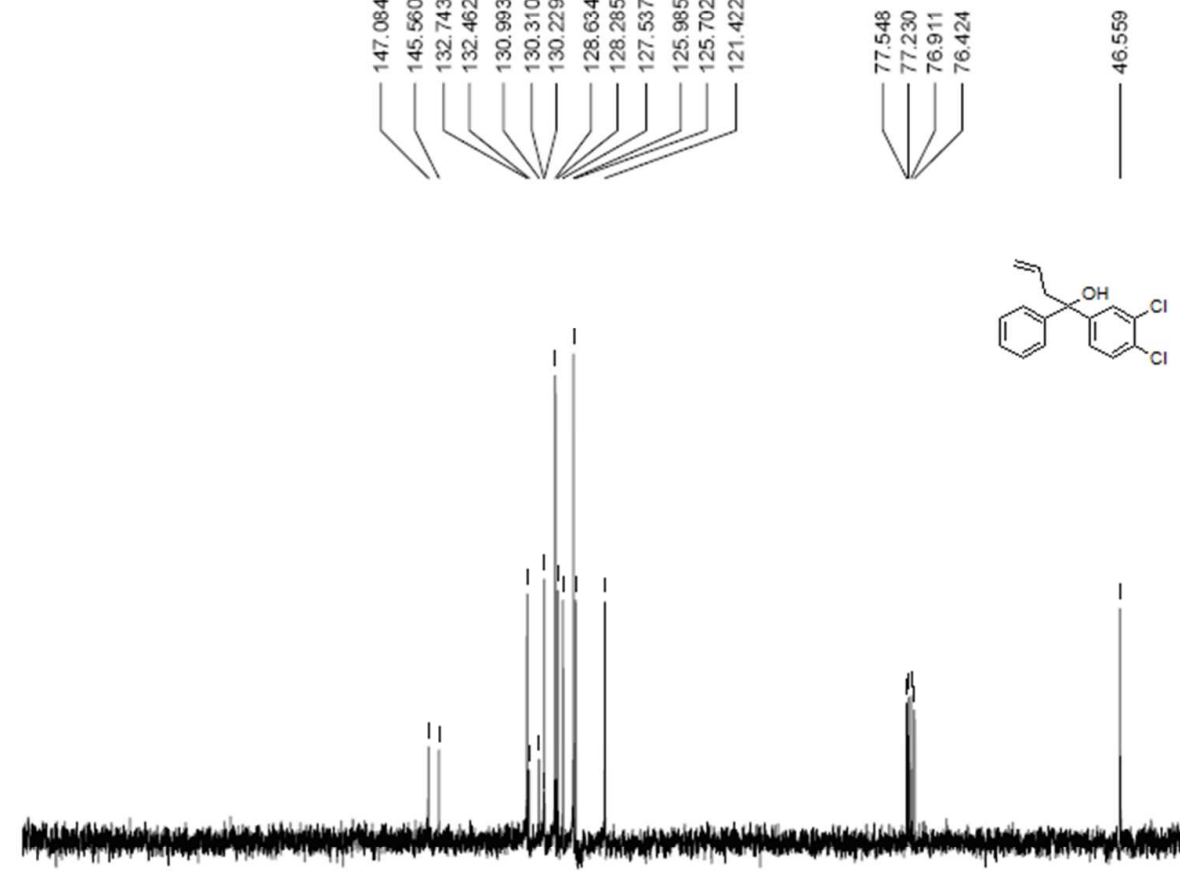

3h 


$4 a$
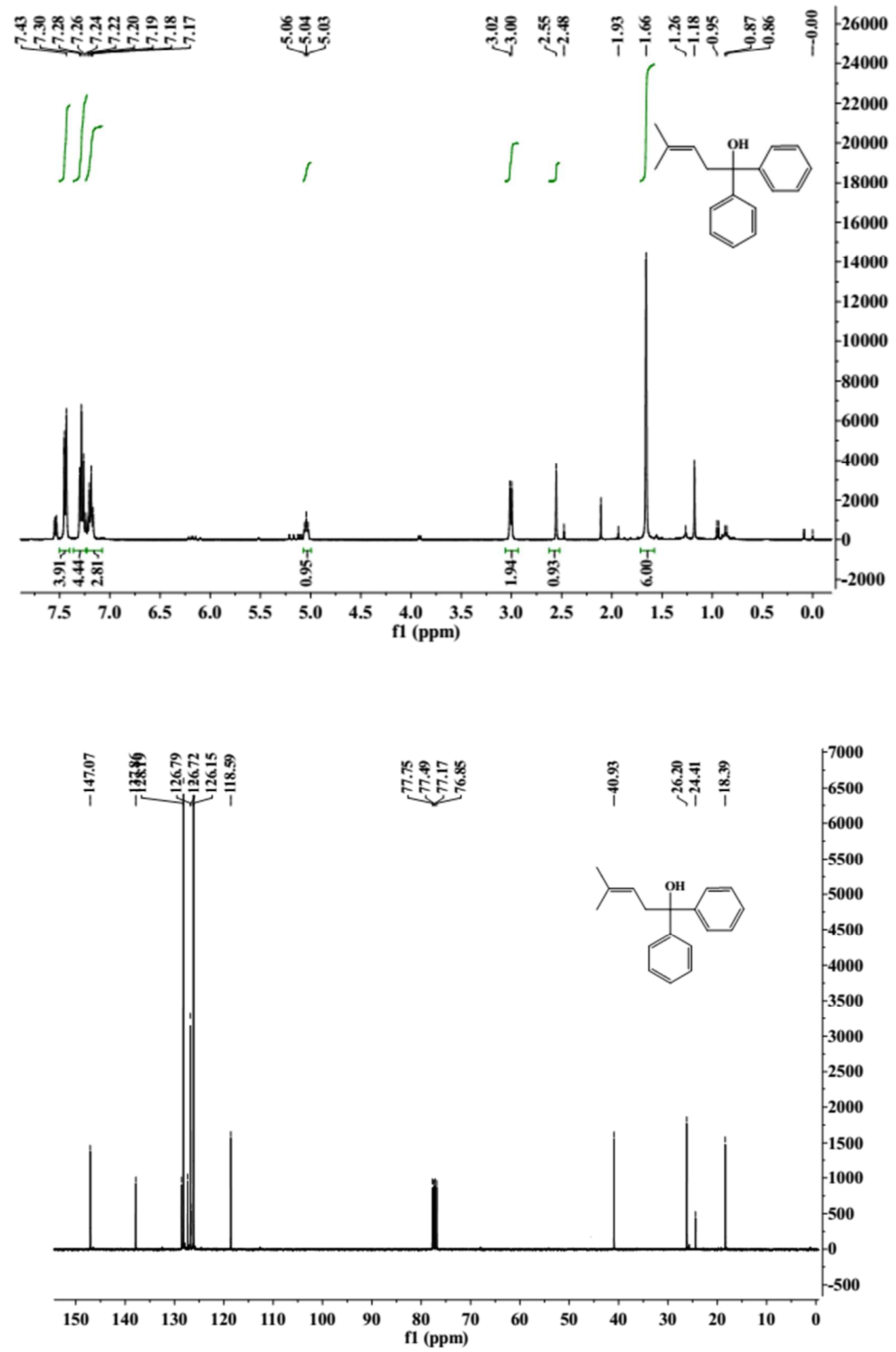


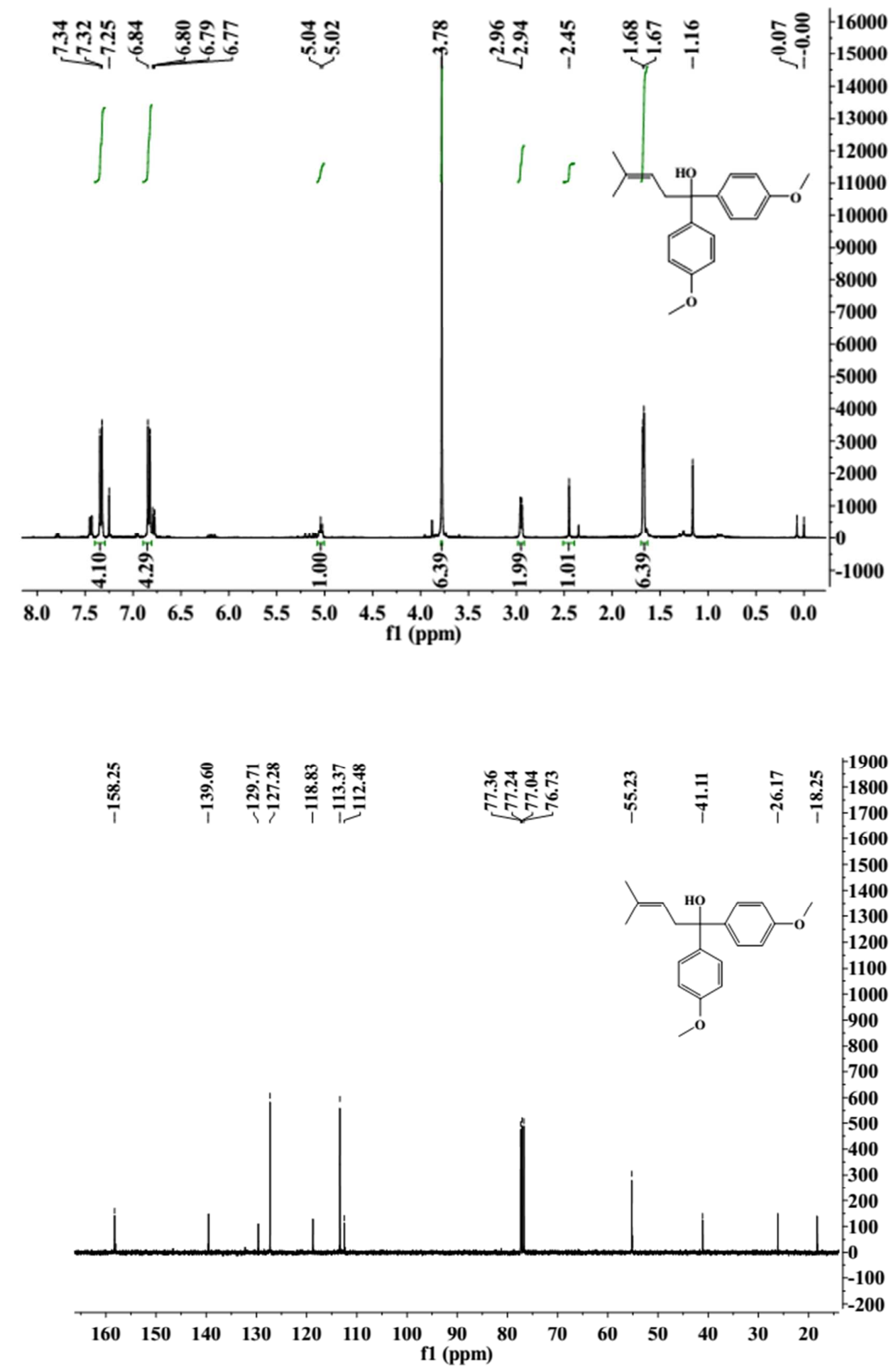



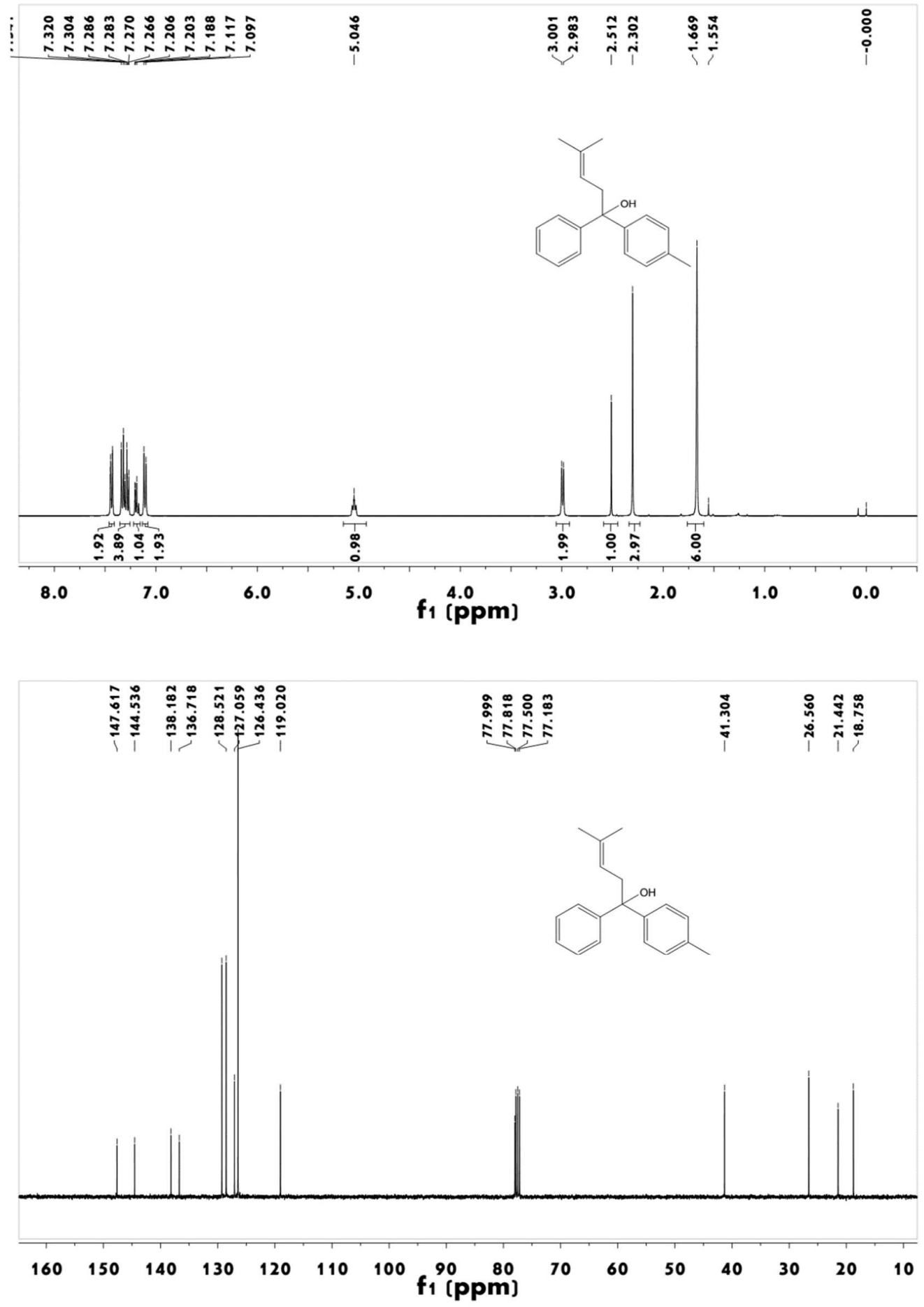
4d


$4 e$ 


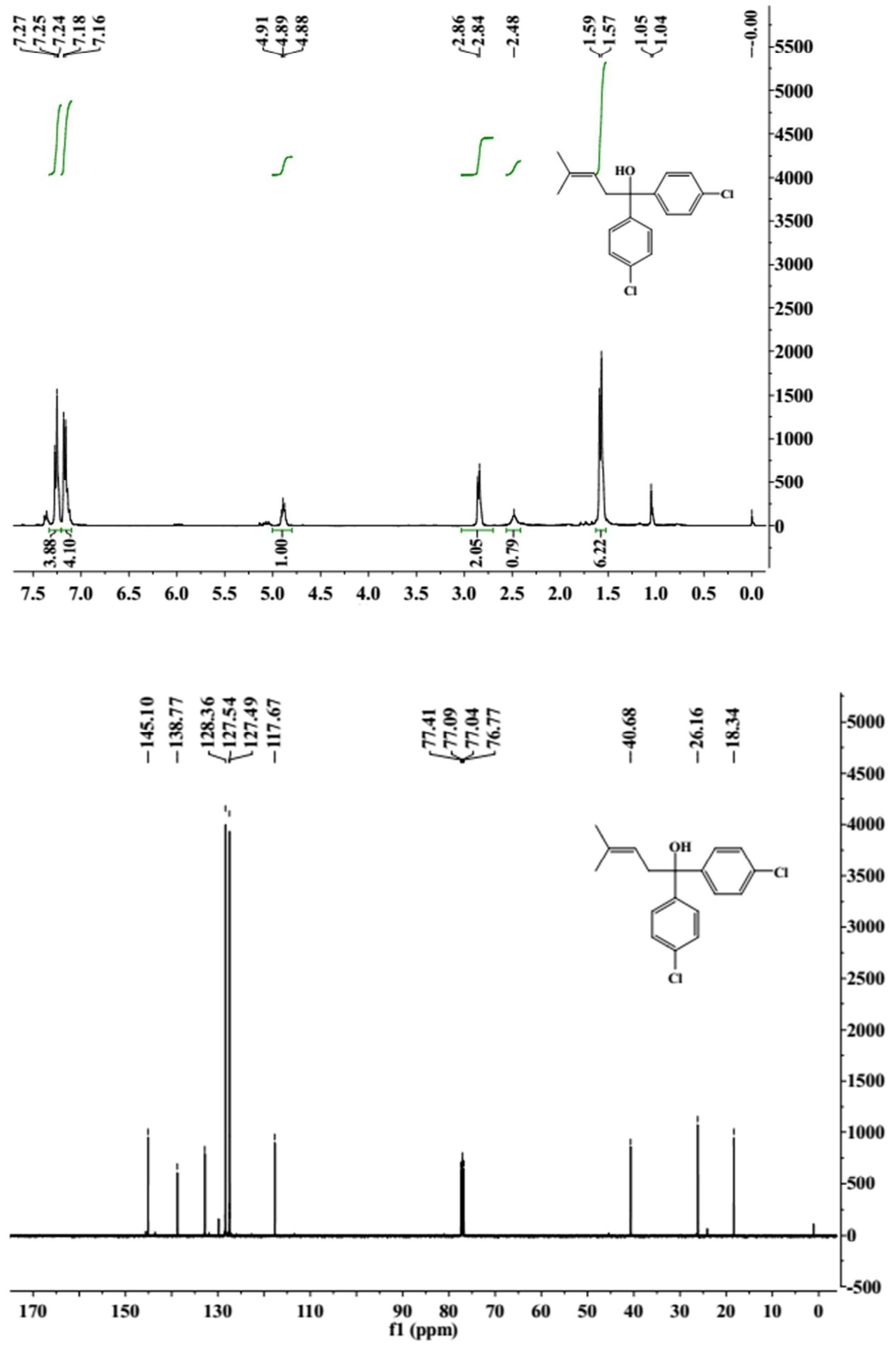



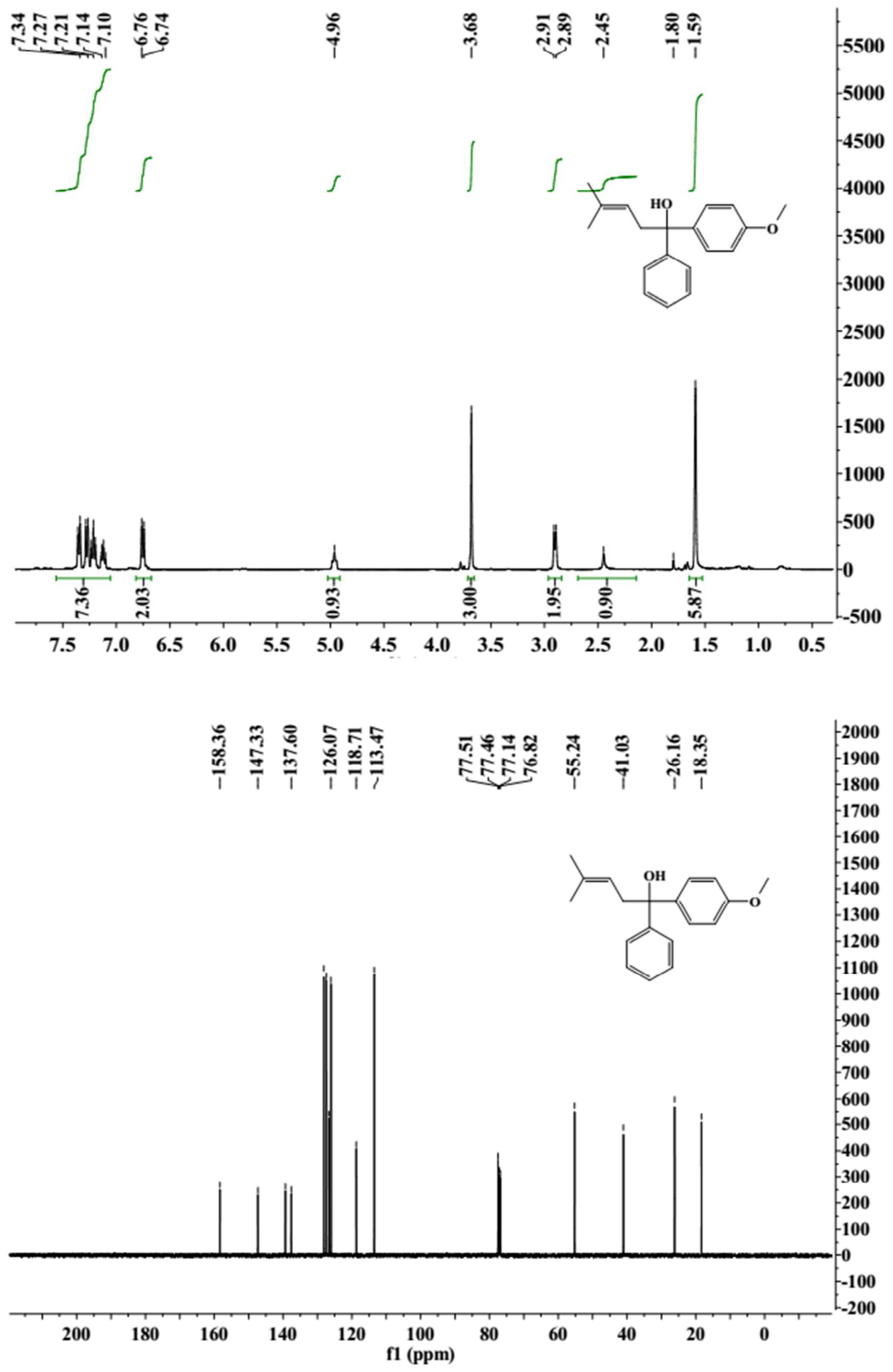

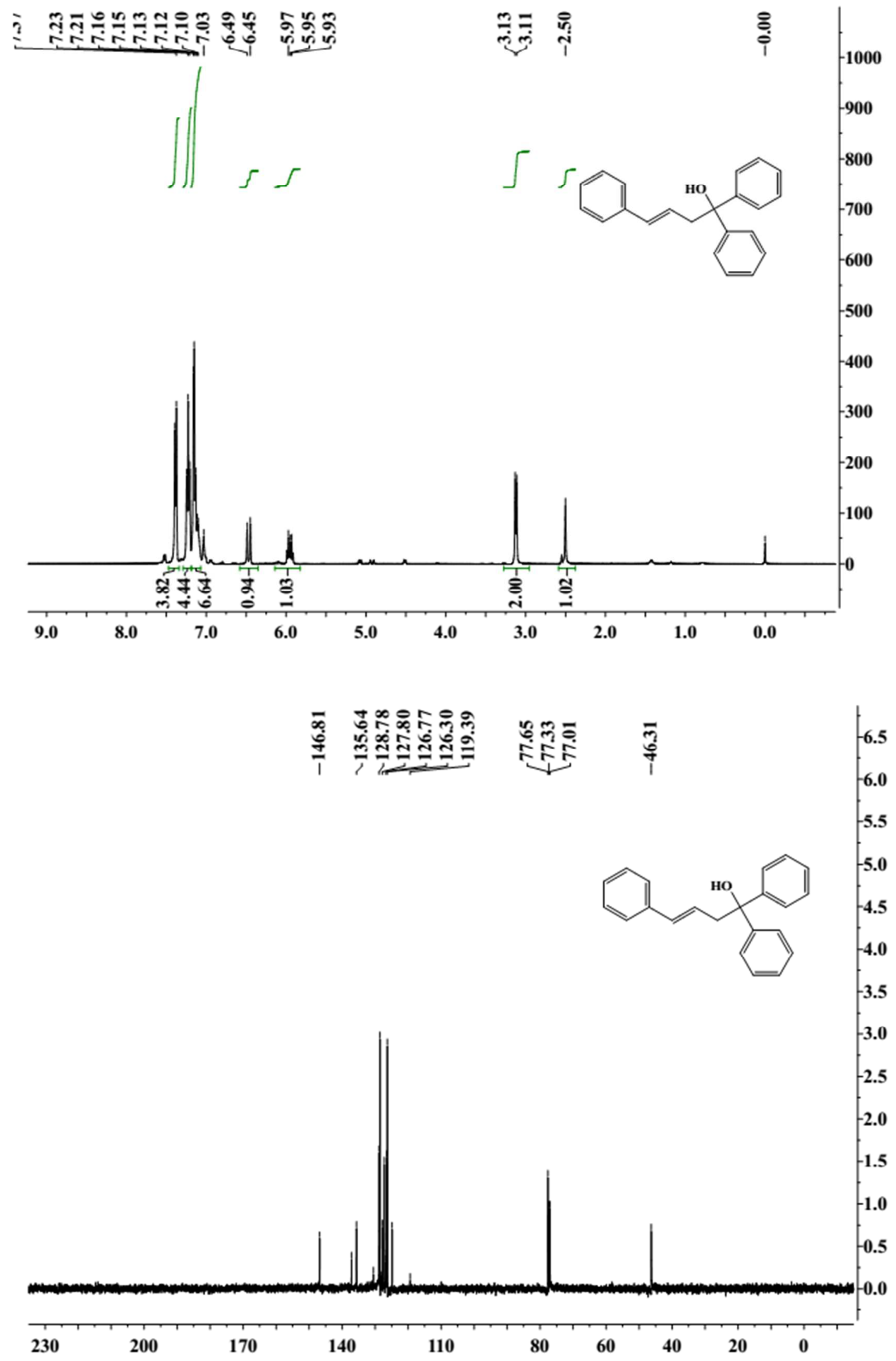

$5 b$ 
药

i⿱

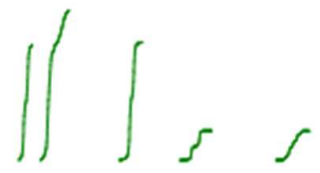

$-32000$

$-30000$

$-28000$

$-26000$

$-24000$

$-22000$

$-20000$

$-18000$

$-16000$

$-14000$

$-12000$

$-10000$

$-8000$

6000

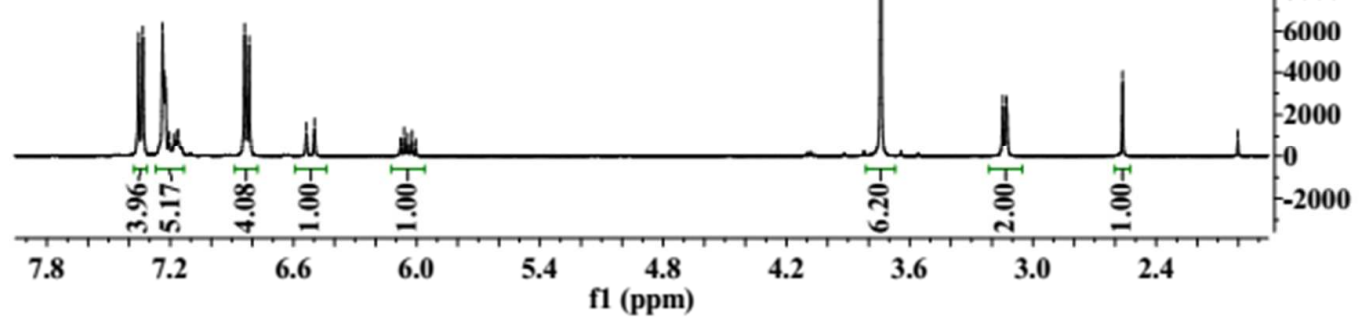

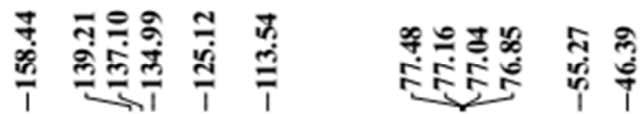

3600

$-3400$

$-3200$

$-3000$

$-2800$

$-2600$

$-2400$

$-2200$

$-2000$

$-1800$

$-1600$

$-1400$

$-1200$

$-1000$

$-800$

$-600$


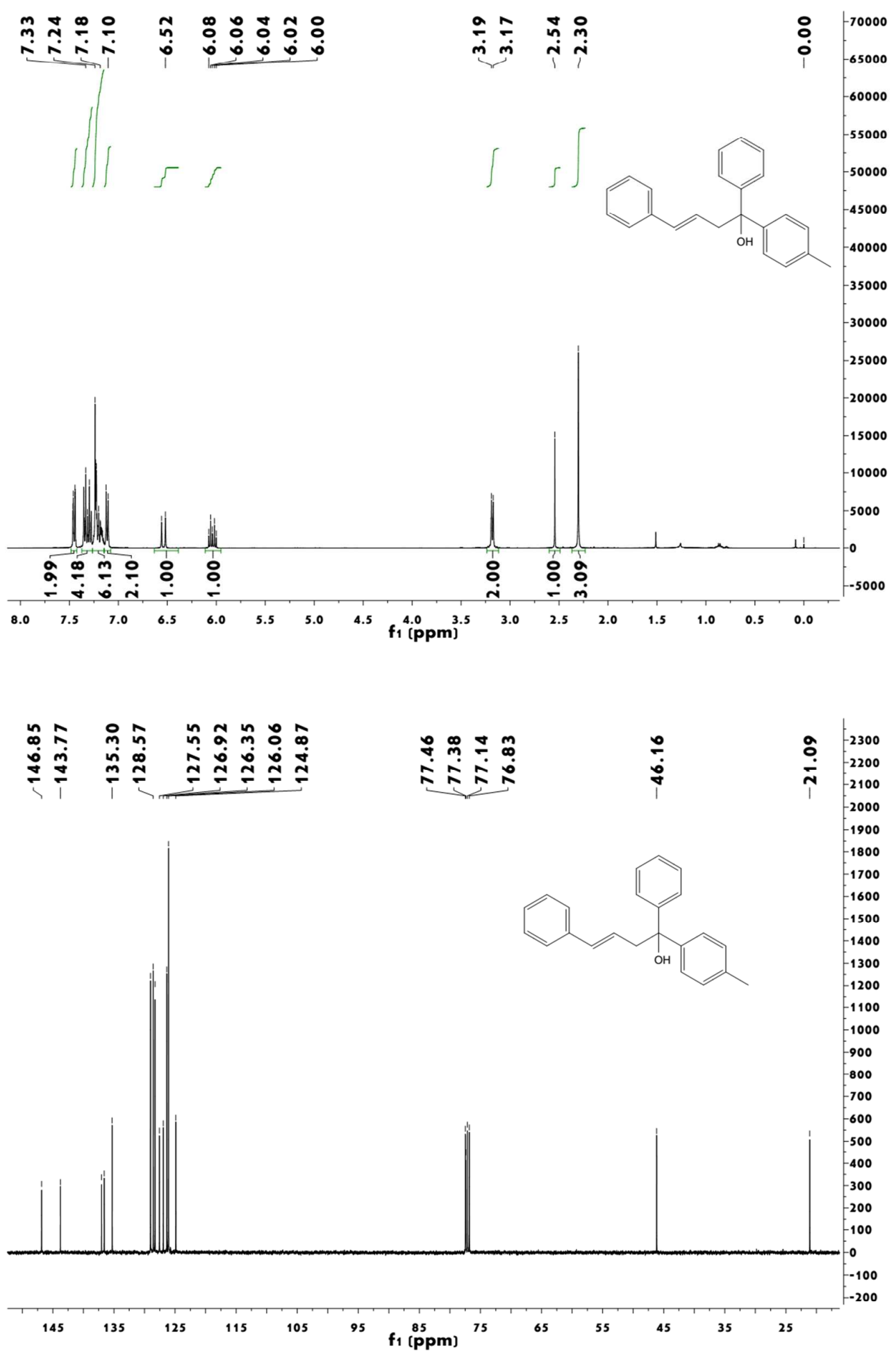


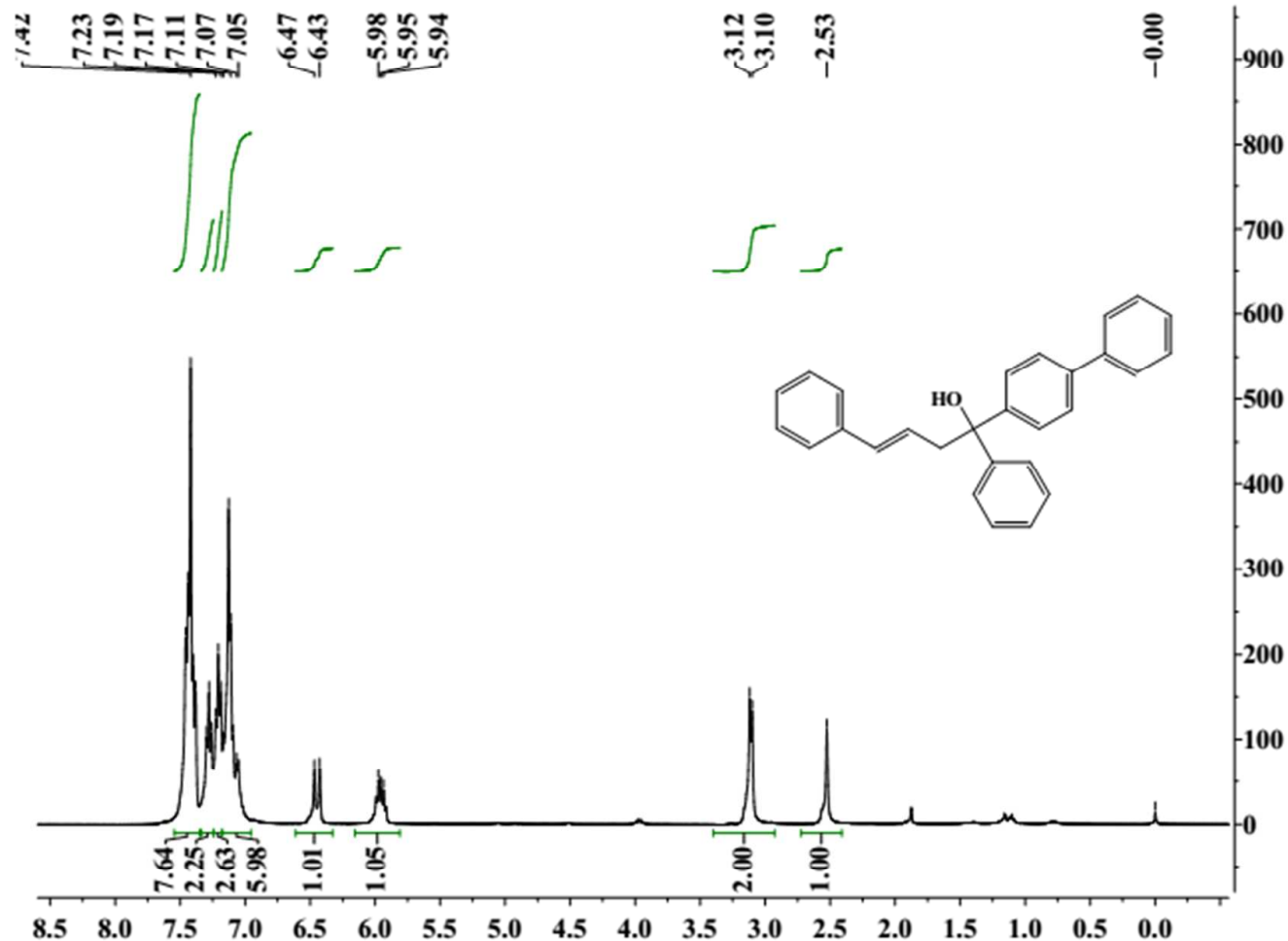


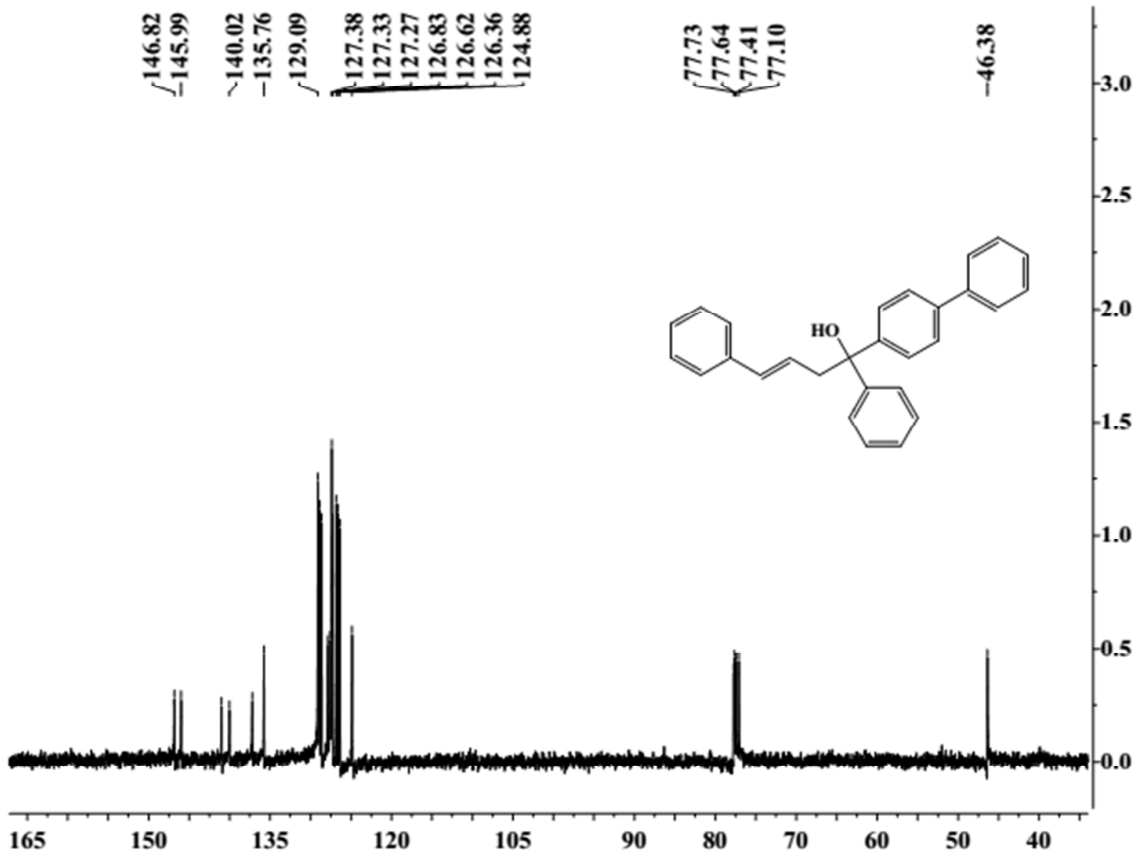

$5 e$ 

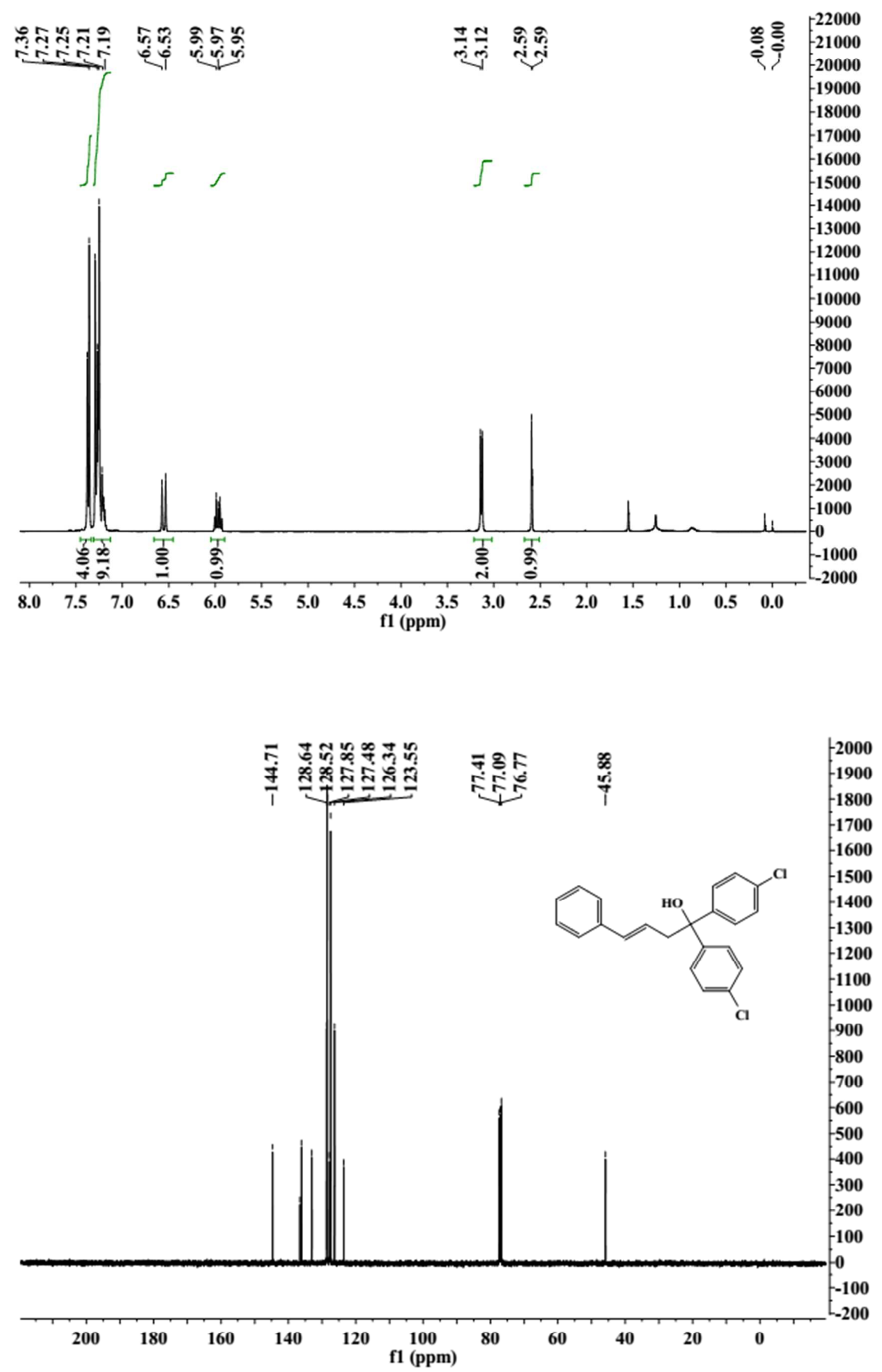


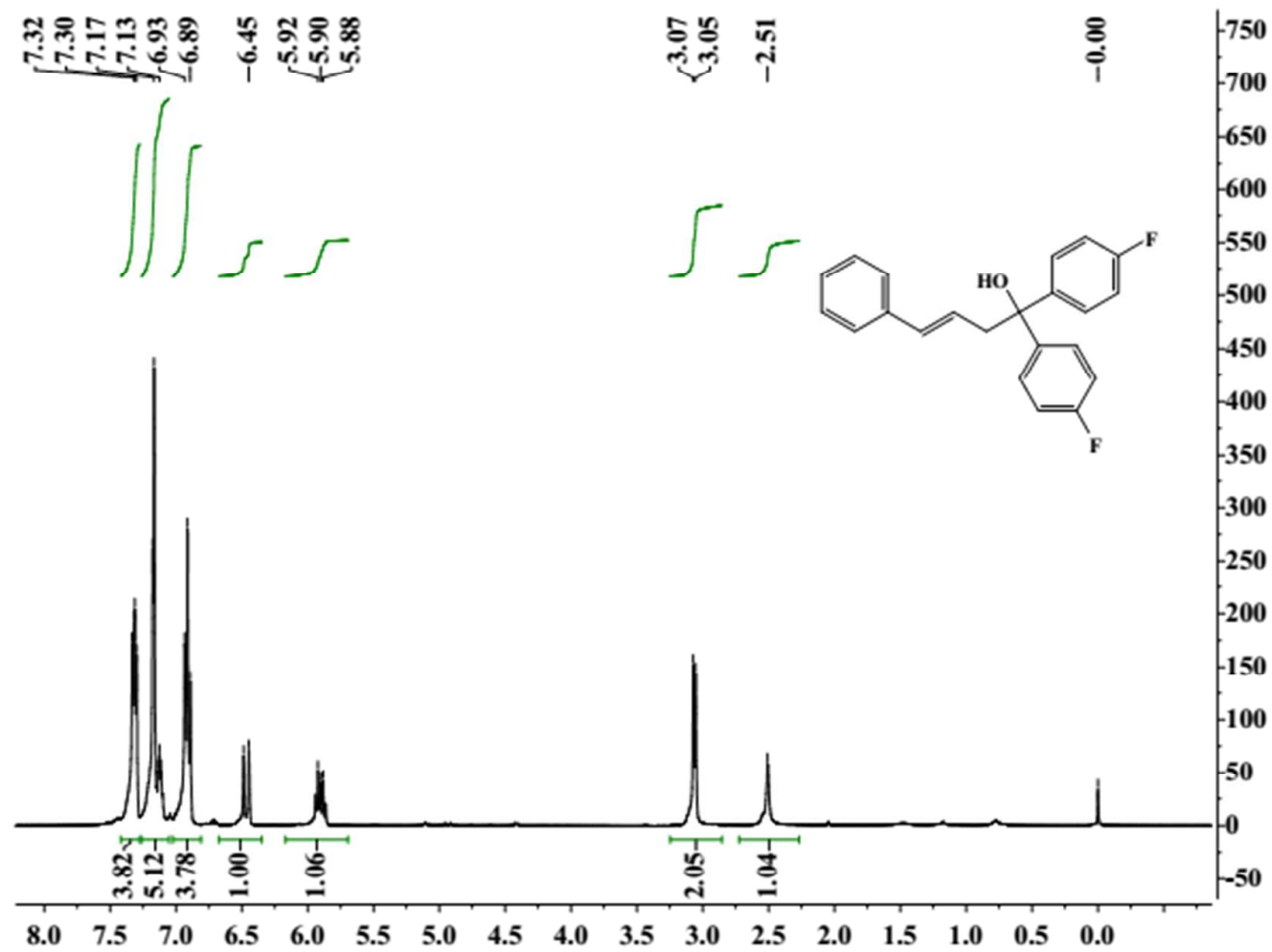

กัฒ

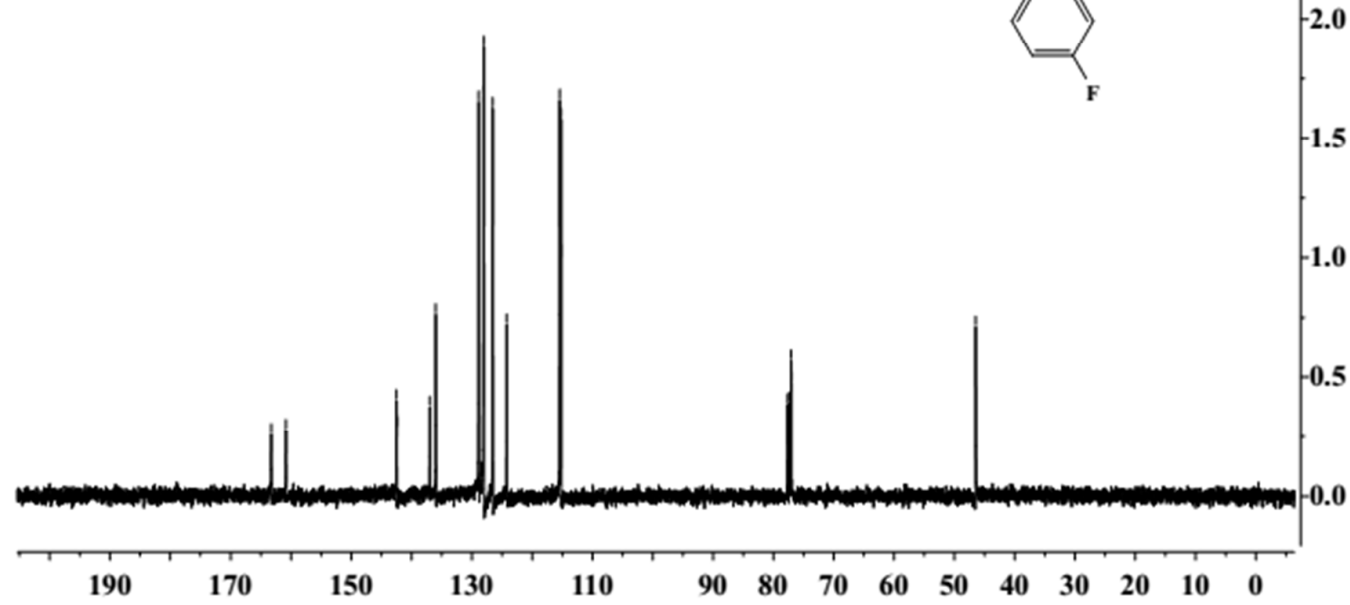



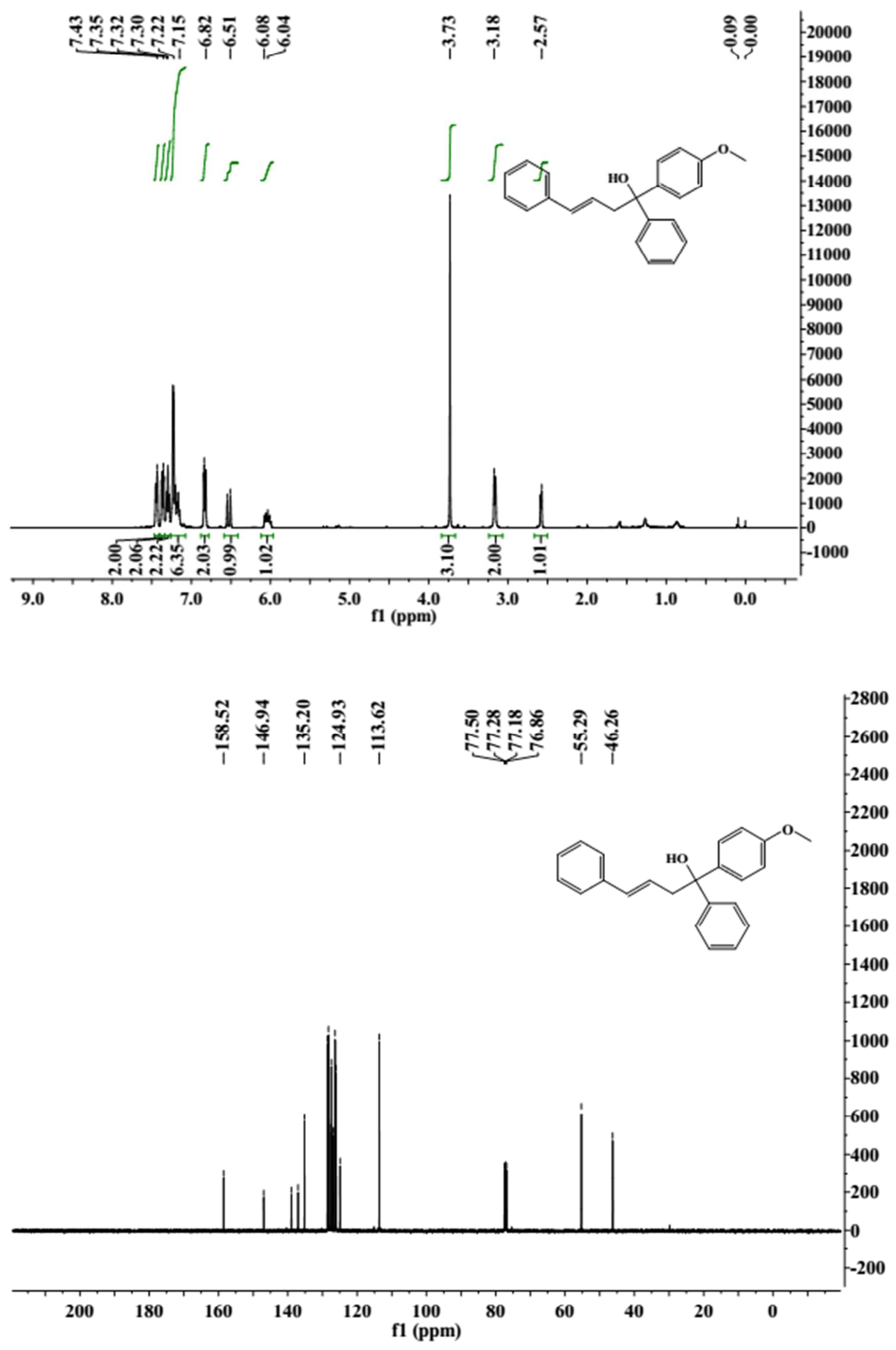

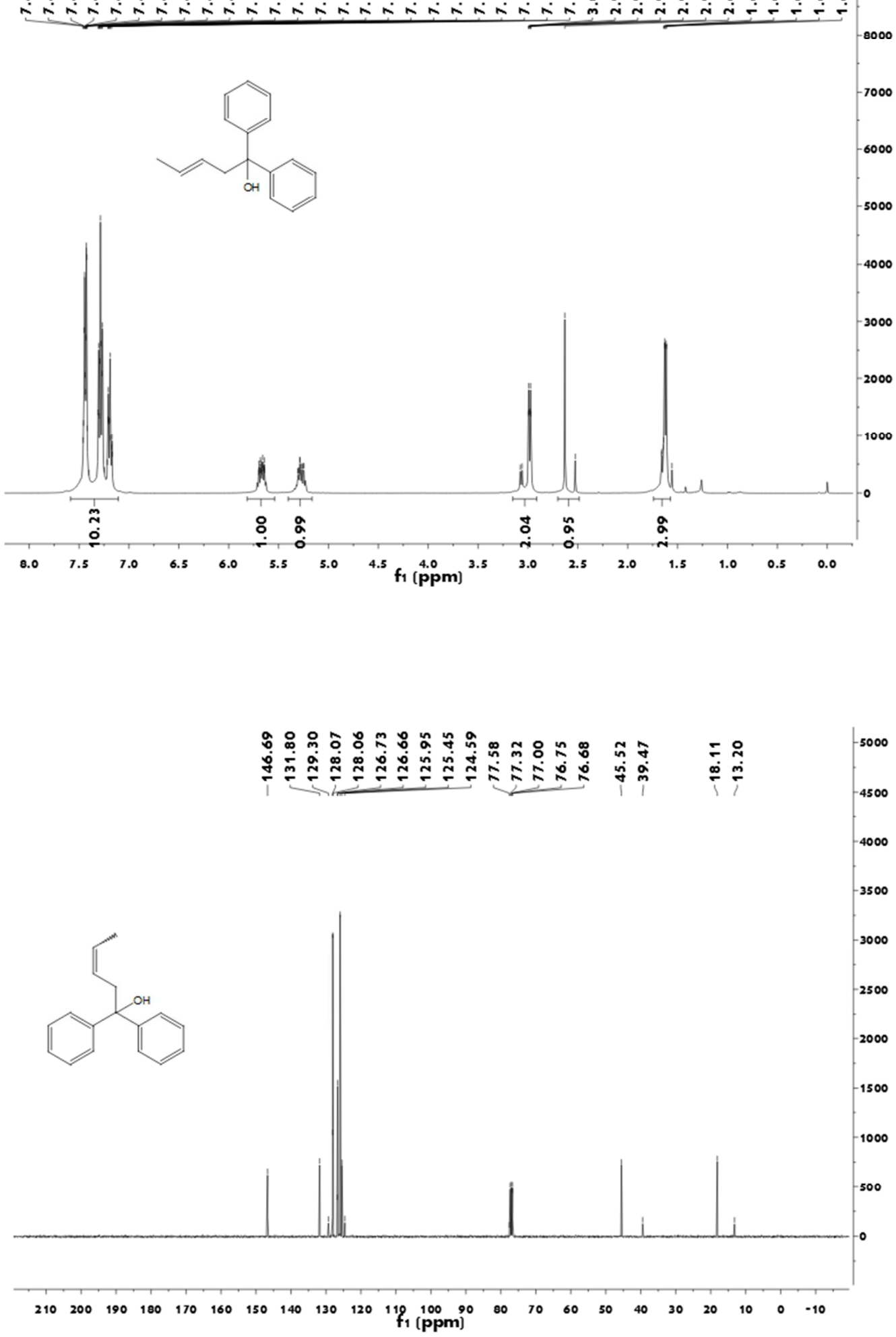
$6 c$
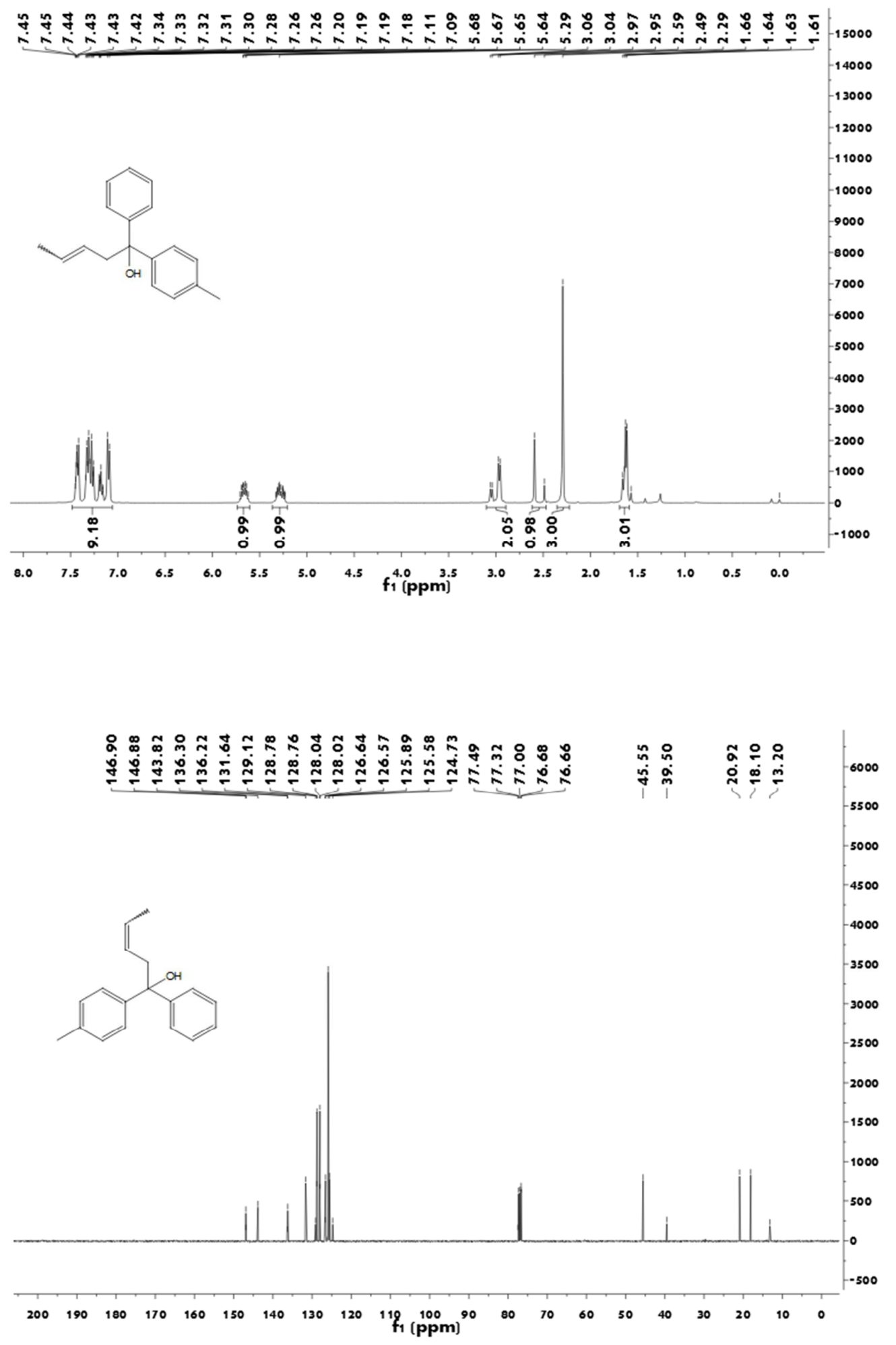